\title{
Somatic Cell Count in Goat Milk: An Indirect Quality Indicator
}

\author{
Klára Podhorecká ${ }^{1, * \mathbb{D}}$, Markéta Borková ${ }^{2}$, Miloslav Šulc ${ }^{3}$, Růžena Seydlová ${ }^{2}$, Hedvika Dragounová ${ }^{2}$, \\ Martina Švejcarová ${ }^{2}$, Jitka Peroutková ${ }^{2}$ and Ondřej Elich ${ }^{2}$ \\ 1 Department of Chemistry, Faculty of Agrobiology, Food and Natural Resources, Czech University of Life \\ Sciences Prague, Kamýcká 129, 16500 Prague, Czech Republic \\ 2 Dairy Research Institute, Ke Dvoru 12a, 16000 Prague, Czech Republic; borkova@milcom-as.cz (M.B.); \\ seydlova@milcom-as.cz (R.S.); dragounova@milcom-as.cz (H.D.); svejcarova@milcom-as.cz (M.š.); \\ peroutkova@milcom-as.cz (J.P.); elich@milcom-as.cz (O.E.) \\ 3 Food Research Institute Prague, Radiova 1285, 10200 Prague, Czech Republic; miloslav.sulc@vupp.cz \\ * Correspondence: podhorecka@af.czu.cz
}

check for updates

Citation: Podhorecká, K.; Borková, M.; Šulc, M.; Seydlová, R.;

Dragounová, H.; Švejcarová, M.; Peroutková, J.; Elich, O. Somatic Cell Count in Goat Milk: An Indirect Quality Indicator. Foods 2021, 10, 1046. https://doi.org/10.3390/foods 10051046

Academic Editors: Lenka Vorlová and Oto Hanuš

Received: 15 April 2021

Accepted: 6 May 2021

Published: 11 May 2021

Publisher's Note: MDPI stays neutral with regard to jurisdictional claims in published maps and institutional affiliations.

Copyright: (c) 2021 by the authors. Licensee MDPI, Basel, Switzerland. This article is an open access article distributed under the terms and conditions of the Creative Commons Attribution (CC BY) license (https:// creativecommons.org/licenses/by/ $4.0 /)$.
Abstract: A high somatic cell count (SCC) impacts dairy quality to a large extent. The goal of this work was to investigate differences in goat milk composition and technological parameters according to SCC cut-off $\left(600,700,800\right.$, and $\left.1000.10^{3} / \mathrm{mL}\right)$. Thirty-four individual milk samples of White Shorthair goats in a similar stage of lactation were investigated. The first differences in milk quality appeared already at SCC cut-off of $600.10^{3} / \mathrm{mL}$ (5.58 LSCS-linear somatic cell score), yet the most striking differences were found for SCC over $1000.10^{3} / \mathrm{mL}$ (6.32 LSCS), which was expressed by lowering heat stability (126 vs. $217 \mathrm{~s}, p=0.034)$, increasing protein ( 3.41 vs. $3.04 \%, p=0.009$ ), casein ( 2.80 vs. $2.44 \%, p=0.034)$ and chloride (164 vs. $147 \mathrm{mg} / 100 \mathrm{~mL}, p=0.004)$ levels, as well as non-fat dry matter $(8.79$ vs. $8.45 \%, p=0.045)$. It has been shown that low levels of Staphylococcus spp. bacteria (120-1600 CFU/mL) in the mammary gland correlated with decreased lactose content (4.60 vs. $4.47 \mathrm{~g} / 100 \mathrm{~g}, p=0.022$ ). Since our results indicate that even low SCC values may significantly affect the technological properties of goat milk, SCC should therefore be routinely screened and reported to dairy manufacturers to assure the consumer of high end-product quality.

Keywords: goat milk; somatic cells; mastitis-causing bacteria (MCB); Staphylococcus spp.; milk quality

\section{Introduction}

Somatic cell count (SCC) is considered an indirect indicator of the milk's hygienic quality. Higher SCC values above a typical physiological range indicate microbial inflammation of the mammary gland. This is not true for goat milk (an apocrine type of milk), which naturally contains higher amounts of epithelium cells and their fragments, arising from epithelial desquamation and physiological regeneration of mammary alveoli $[1,2]$. For this reason, raw goat milk typically has a higher SCC compared to cow milk.

Somatic cells are a natural component of milk, and they comprise epithelial cells (as mentioned above) and leukocytes (white blood cells) [3]. Leukocytes play an important role in an animal's immune response, their main task being to protect the body against foreign invaders (e.g., pathogenic bacteria) [2]. There are many types of leukocytes found in milk, such as macrophages, lymphocytes, and polymorphonuclear leukocytes (PMN), the ratios of which differ by animal species. PMN are the main leukocyte type found in the milk of healthy goats [4,5] compared to cow and sheep milk, which predominantly contains macrophages [3]. Mastitis increases PMN content in cow and sheep milk, but not in goat milk, in which they still represent the dominant type $[4,5]$.

Enzymes in milk are of endogenous origin (originating from somatic cells, blood plasma, or fat globule membranes) or exogenous origin (microbial enzymes). Somatic cells are a source of a variety of enzymes which characterize each type of leukocyte. Macrophages and PMN (the most abundant leukocytes in the milk of healthy cows and 
goats) are an important source of proteases such as lysosomal cathepsin and elastase enzymes [6].

Plasmin is the major proteolytic enzyme in milk [7], and it is commonly found in milk produced by both healthy and diseased mammary glands [8]. It is formed from its zymogen (plasminogen) catalyzed by plasminogen activator protein, which is likely produced by somatic cells such as macrophages [7]. Plasmin synthesis and function is a good example how somatic cells in milk might directly affect the composition and technological parameters of goat milk. To date we still don't have a complete picture of the role of enzymes in milk (e.g., plasmin and other endogenous enzymes produced by somatic cells) and the factors that contribute to their activity. It is likely that these enzymes cause postsecretional changes in milk composition and impact its quality, as well as its technological parameters.

Raynal-Ljutovic et al. [9] have shown that somatic cells exert proteolytic activity that alters casein fractions, which, in turn, impact technological properties (e.g., lowering curd firmness). Endogenous enzymes found in somatic cells may even influence organoleptic properties of milk [10].

Typically, goat milk contains high SCC levels on average (e.g., 1100 resp. $1300.10^{3} / \mathrm{mL}$ ) as found by Bogdanovičová et al. [11] and Novotná et al. [12]. Such values are alarming, and it is necessary to investigate the causes for these high values and how they impact goat milk quality. High SCC values found in milk from healthy (mastitis-free) goats should therefore be a clear signal as to whether such milk is suitable for technological processing in a dairy plant. The goal of this research was to shed some light on how different SCC levels $\left(600,700,800\right.$, and $\left.1000.10^{3} / \mathrm{mL}\right)$ affect the qualitative, quantitative, and technological properties of milk from healthy goats.

\section{Materials and Methods}

\subsection{Chemicals}

Chymosin enzyme (Chr. Hansen, Avedore, Denmark); ammonium thiocyanate solution, silver nitrate (Lach-ner, s.r.o., Neratovice, Czech Republic); ammonium iron (III) sulfate dodecahydrate ACS grade (VWR International, s.r.o., Stříbrná Skalice, Czech Republic); nitric acid 67\%, Analpure grade (Analytika ${ }^{\circledR}$, spol. s.r.o., Prague, Czech Republic) was purchased.

\subsection{Farm and Animals}

One of the largest organically operated goat farms in the Czech Republic (500 heads in 2020), which enabled a sufficient number of animals of the same breed and kept in the same conditions to be obtained, was selected for the study. In total, 34 White Shorthair goats in their second or third lactation (parturitions between 7-27 March 2020), housed in the same environment and fed with uniformed ration (consisting of fed hay, haylage, pasture, and granulated concentrated feed), were included in the study.

\subsection{Milk Sampling, Milking}

Thirty-four individual milk samples were taken by manual milking between 18-25 August 2020. The milking was carried out by the farm personnel in disposable sterile gloves in the following way: the udder was washed, the teats wiped with a single-use disinfecting wipe, the first couple of jets were discarded, the further jets were collected separately into sterile bottles (for MCB, TMC), and manual milking ensued. The milk samples were cooled down to $4-6^{\circ} \mathrm{C}$ and immediately transported to the laboratories for further analyses.

\subsection{Testing Laboratories}

Microbiological testing was performed by Dairy Research Institute (Prague, Czech Republic) and veterinary laboratory VEDIA (Strakonice, Czech Republic); chemical and 
technological testing was performed by Dairy Research Institute (Prague, Czech Republic) and Czech University of Life Sciences (Prague, Czech Republic).

\subsection{Methods}

\subsubsection{Somatic Cell Count (SCC)}

SCC was measured in cassettes by DeLaval Cell Counter (DeLaval, Stockholm, Sweden) on site directly after milking. The SCC values were transformed into a linear somatic cell score (LSCS) using the conversion LSCS $=3+\log _{2}(\mathrm{SCC} / 100)$, according to Wiggans and Shook (1987) [13], in order to normalize the data.

\subsubsection{Total Microbial Count (TMC), Identification of Bacteria and Their Count}

TMC was quantified using GTK-M agar plates (MILCOM a.s., Tábor, Czech Republic) by culturing at $30{ }^{\circ} \mathrm{C}$ for $72 \mathrm{~h}$ under the aerobic conditions, according to ČSN EN ISO 4833-1 [14], which is the Czech equivalent of ISO 4833-1.

Identification of bacteria and their count: pathogenic bacteria in milk were determined by the Veterinary Laboratory Vedia s.r.o. (Strakonice, Czech Republic). The presence of coliform bacteria, staphylococci, streptococci, and corynebacteria was monitored. Basic cultivation of bacteria occurred on the Columbia blood agar (Oxoid, UK). ENDO agar (Oxoid, UK) was used to cultivate coliform bacteria. Enterococcus Selective Agar-BAA (Oxoid, UK) was used to distinguish streptococci and enterococci, and Edwards agar (Oxoid, UK) was used for streptococcal culture, and for staphylococci, Baird-Parker agar (Oxoid, UK) and Staphylococcus agar (Sigma-Aldrich, USA) was applied. A coagulase test was used to distinguish between coagulase-negative and -positive staphylococci (Staphylase Test, Oxoid, UK).

When necessary, a microflex LT MALDI TOF mass spectrometer (Bruker Daltonics, Bremen, Germany) with a microSCOUT ion source and a TOF flight time analyzer (Bruker Daltonics, Bremen, Germany) in conjunction with the MALDI Biotyper software system (Bruker Daltonics, Bremen, Germany) was used to identify bacterial species.

\subsubsection{Rennetability (Chymosin-Induced Coagulation)}

Milk rennetability was measured, in line with Desobry-Banon et al. [15], as time needed for the milk to start curdling after chymosin enzyme addition. One $\mathrm{m}$ of freshly prepared chymosin solution (equivalent to curdling activity 100,000) was added to $100 \mathrm{~mL}$ of milk kept at $35^{\circ} \mathrm{C}$, gently swirled, and the appearance of the first curds was observed.

\subsubsection{Heat Stability (Thermostability)}

A modified method by Robitaille and Ayers [16] was used in which the heat stability is measured as time needed for the milk to begin curdling by heat treatment. $2.5 \mathrm{~mL}$ of milk was pipetted into a glass test tube (Pyrex test tubes $10 \times 0.75 \mathrm{~cm}$ ) and stoppered with a silicone rubber. The test tubes were immersed in a thermostatically controlled oil bath heated to $140{ }^{\circ} \mathrm{C}$, and the appearance of the first curds was observed.

\subsection{5. $\mathrm{pH}$}

The $\mathrm{pH}$ was measured by a glass electrode using SensION+ $\mathrm{pH} 1$ instrument (Hach, Prague, Czech Republic) calibrated daily with buffers $\mathrm{pH} 4.00$ and 7.00.

\subsubsection{Fat, Protein, Lactose, Casein, Non-Fat and Total Dry Matter, Chlorides}

The milk was analyzed on DairySpec FT (Bentley Instruments) that was calibrated with goat milk samples using the following reference methods: fat (ČSN EN ISO 1211 [17], the Czech equivalent of ISO 1211), protein (ČSN EN ISO 8968-1 [18], the Czech equivalent of ISO 8968-1), casein (ČSN ISO 17997-1 [19], the Czech equivalent of ISO 17997-1), lactose (IDF 79-2) [20], non-fat and total dry matter (ČSN ISO 6731 [21], the Czech equivalent of ISO 6731). 
Chlorides were quantified by argentometry (in three replicates), using $0.1 \mathrm{M}$ ammonium thiocyanate solution in line with ČSN 570530 [22]. To $10 \mathrm{~g}$ of milk sample, $5 \mathrm{~mL}$ of $25 \%$ of nitric acid and $1 \mathrm{~mL}$ of saturated ammonium iron (III) sulfate solution (indicator) was added and carefully mixed, followed by $10 \mathrm{~mL}$ of $0.1 \mathrm{M}$ silver nitrate and titrated.

\subsection{Statistics}

Statistical analyses were performed by Dell ${ }^{\mathrm{TM}}$ Statistica ${ }^{\mathrm{TM}} 13.1$ software (Dell Inc., Round Rock, TX, USA). The non-parametric data in our study were analyzed using the Kruskal-Wallis test for independent variables $(p<0.05)$. For more in-depth statistical details, Dunn's multiple comparison test was carried out. The descriptive statistics use medians; however, for better comparison of results in tables, means and standard deviations (SD) are also used.

\section{Results and Discussion}

Goat milk quality and composition is influenced by many factors, such as breed type, feeding, lactation stage, lactation number, kidding date, and overall health condition [23,24]. In this experiment, we tried to reduce the influence of these factors on how SCC affects milk quality and composition. Therefore, our animals were housed at the same farm, were fed the same diet, had the same kidding date (7-27 March 2020) and were in the same lactation stage. Only animals with no obvious udder or teat problems (redness, etc.) were included in the experiment. Twelve milk samples came from goats on the second lactation and 22 samples from goats on the third lactation. Because no statistically significant differences in any milk parameter (see Table 1) regarding the lactation number were found, the influence of the lactation number was further disregarded, and thus we were able to work with a larger set of data (34 in total). Nevertheless, this dataset is not extensive due to the very careful selection and correction for factors such as breeding environment, kidding date, lactation phase, etc.

Table 1. Microbiological, chemical, and technological parameters of goat milk samples according to lactation number.

\begin{tabular}{|c|c|c|c|c|c|}
\hline \multirow{3}{*}{ Samples (n) } & \multicolumn{2}{|c|}{ 2nd } & \multicolumn{2}{|c|}{ 3rd } & \multirow{3}{*}{$p$} \\
\hline & \multicolumn{2}{|c|}{12} & \multicolumn{2}{|c|}{22} & \\
\hline & Mean & SD & Mean & SD & \\
\hline $\operatorname{SCC}\left(10^{3} / \mathrm{mL}\right)^{1}$ & 1456 & 1215 & 1338 & 1009 & 0.857 \\
\hline $\mathrm{LSCS}^{2}$ & 6.33 & 1.35 & 6.35 & 1.11 & 0.857 \\
\hline Milk yield (mL) & 617 & 168 & 561 & 160 & 0.304 \\
\hline Rennetability (s) & 155 & 60.5 & 146 & 33.1 & 0.885 \\
\hline Heat stability (s) & 171 & 96.9 & 162 & 107 & 0.900 \\
\hline $\mathrm{pH}$ & 6.84 & 0.12 & 6.81 & 0.09 & 0.322 \\
\hline $\log \mathrm{TMC}(\mathrm{CFU} / \mathrm{mL})^{3}$ & 1.74 & 1.12 & 2.18 & 0.97 & 0.288 \\
\hline $\log$ Staph. (CFU/mL) & 1.44 & 0.76 & 1.80 & 0.73 & 0.256 \\
\hline Fat $(\mathrm{g} / 100 \mathrm{~g})$ & 5.07 & 0.78 & 5.66 & 1.27 & 0.220 \\
\hline Protein (g/100 g) & 3.13 & 0.49 & 3.27 & 0.26 & 0.377 \\
\hline Casein $(\mathrm{g} / 100 \mathrm{~g})$ & 2.53 & 0.44 & 2.62 & 0.30 & 0.368 \\
\hline Lactose (g/100 g) & 4.60 & 0.17 & 4.54 & 0.17 & 0.272 \\
\hline Chlorides (mg/100 g) & 157 & 10.06 & 155 & 13.90 & 0.540 \\
\hline $\operatorname{NFDM}(\mathrm{g} / 100 \mathrm{~g})^{4}$ & 8.55 & 0.50 & 8.58 & 0.29 & 0.746 \\
\hline $\operatorname{TDM}(\mathrm{g} / 100 \mathrm{~g})^{5}$ & 13.5 & 0.97 & 14.2 & 1.21 & 0.242 \\
\hline
\end{tabular}

${ }^{1}$ SCC—somatic cell count; ${ }^{2}$ LSCS—linear somatic cell score; ${ }^{3}$ TMC—-total microbial count; ${ }^{4}$ NFDM-non-fat dry matter; ${ }^{5}$ TDM-total dry matter.

Milk quality is affected by bacteria [25]. Therefore, the herd was screened for mastitiscausing bacteria (MCB), which has oftentimes been neglected in other studies investigating SCC (linear somatic cell score (LSCS), resp.) in relation to milk quality. MCB were detected in the range of 120 to $1600 \mathrm{CFU} / \mathrm{mL}$ in 11 milk samples (32.4\%), most often as Staphylococcus PK-(delta hemolysin negative), rarely as Staphylococcus PK-(delta hemolysin positive) and only in two cases as Staphylococcus aureus (120 and $340 \mathrm{CFU} / \mathrm{mL}$, resp.). Both S. aureus samples were within the allowed legislative requirements for raw goat milk (S. aureus < 
$500 \mathrm{CFU} / \mathrm{mL}$ and TMC $<500 \times 10^{3} / \mathrm{mL}$ ), and thus could have otherwise been used for dairy manufacturing. On the other hand, for pasteurized goat milk, there are no limits set by the legislation for $S$. aureus, yet TMC must be $<1500 \times 10^{3} \mathrm{CFU} / \mathrm{mL}$ [26]. In our samples, TMC did not exceed $7300 \mathrm{CFU} / \mathrm{mL}$ (mean $=633 \mathrm{CFU} / \mathrm{mL}$ ), thus no significant microbial colonization of the mammary gland was revealed, and all milk samples were of a very good hygienic standard.

Table 2 presents results grouped according to detected SCC (LSCS, resp.) and MCB. Staphylococcus spp. distribution (disregarding SCC) is similar in L and H group (27.3-35.3\%, Table 3). Higher SCC levels in our study might have been caused by factors other than $\mathrm{MCB}$, e.g., the animal's physiology, genotype [27], or by other non-infectious factors such as estrus, seasonal influences, or parity [28,29]. External stresses experienced by the animal can also influence milk SCC [2,29]. The even distribution of Staphylococcus spp. bacteria (MCB) in our samples might have been caused by the above Staphylococcus types as well as by their actual low counts. Leitner et al. [25] and Bagnicka et al. [5] showed that coagulasenegative Staphylococci are the most often detected MCB with subclinical manifestation, which might not express itself in an elevated SCC. A different situation can be observed in the presence of $S$. aureus in milk, which always raises SCC levels $[5,30]$. This is in line with our observation of the two $S$. aureus positive milk samples which had an SCC above $1000.10^{3} / \mathrm{mL}$ (6.32 LSCS).

Table 2. Number of samples (n) according to SCC and MCB (Staph. count).

\begin{tabular}{|c|c|c|c|c|c|}
\hline Group & \multirow[t]{2}{*}{$\begin{array}{l}\text { Staph. Count } \\
\text { (CFU/mL) }\end{array}$} & \multicolumn{4}{|c|}{ Samples (n) } \\
\hline $\operatorname{SCC}\left(10^{3} / \mathrm{mL}\right)^{1}$ & & $<600$ & $<700$ & $<800 *$ & $<1000$ \\
\hline $\operatorname{LSCS}^{2}$ & & $<5.58$ & $<5.81$ & $<6.00$ & $<6.32$ \\
\hline $\mathrm{LZ}$ & $<100$ & 8 & 9 & 10 & 12 \\
\hline LB & $>100$ & 3 & 4 & 4 & 5 \\
\hline $\mathrm{L}$ & all & 11 & 13 & 14 & 17 \\
\hline $\operatorname{SCC}\left(10^{3} / \mathrm{mL}\right)^{1}$ & & $>600$ & $>700$ & $>800 *$ & $>1000$ \\
\hline LSCS $^{2}$ & & $>5.58$ & $>5.81$ & $>6.00$ & $>6.32$ \\
\hline $\mathrm{HZ}$ & $<100$ & 15 & 14 & 13 & 11 \\
\hline $\mathrm{HB}$ & $>100$ & 8 & 7 & 7 & 6 \\
\hline $\mathrm{H}$ & all & 23 & 21 & 20 & 17 \\
\hline $\mathrm{LBHZHB}\left(\sum \mathrm{LB}+\mathrm{HZ}+\mathrm{HB}\right)$ & all & - & - & - & 22 \\
\hline Total samples $(\mathrm{LZ}+\mathrm{LB}+\mathrm{HZ}+\mathrm{HB})$ & all & \multicolumn{4}{|c|}{34} \\
\hline $\mathrm{Z}(=\mathrm{LZ}+\mathrm{HZ})$ & $<100$ & \multicolumn{4}{|c|}{23} \\
\hline $\mathrm{B}(=\mathrm{LB}+\mathrm{HB})$ & $>100$ & \multicolumn{4}{|c|}{11} \\
\hline
\end{tabular}

* SCC cut-off 900 doesn't exist because no investigated milk sample contained SCC $900-999.10^{3} / \mathrm{mL} .{ }^{1} \mathrm{SCC}$-somatic cell count; ${ }^{2}$ LSCS-linear somatic cell score.

Table 3. Percentage (\%) of MCB (positive samples with Staph. count $>100 \mathrm{CFU} / \mathrm{mL}$ ).

\begin{tabular}{ccccc}
\hline SCC Cut-Off $\left(\mathbf{1 0}^{\mathbf{3}} / \mathbf{m L}\right)^{\mathbf{1}}$ & $\mathbf{6 0 0}$ & $\mathbf{7 0 0}$ & $\mathbf{8 0 0}$ & $\mathbf{1 0 0 0}$ \\
\hline LSCS $^{2}$ & 5.58 & 5.81 & 6.00 & 6.32 \\
\hline LB out of L (SCC < cut-off) & 27.3 & 30.8 & 28.6 & 29.4 \\
HB out of H (SCC >cut-off) & 34.8 & 33.3 & 35.0 & 35.3 \\
\hline
\end{tabular}

* SCC cut-off 900 doesn't exist because no investigated milk sample contained SCC $900-999.10^{3} / \mathrm{mL} .{ }^{1}$ SCC-somatic cell count; ${ }^{2}$ LSCS-linear somatic cell score.

Only milk samples with a Staph. count up to $100 \mathrm{CFU} / \mathrm{mL}$ were included in further SCC analysis (samples with Staph. count $>100 \mathrm{CFU} / \mathrm{mL}$ were excluded due to the excessive presence of MCB). Therefore, it can be assumed that samples with a low Staph. count $(<100 \mathrm{CFU} / \mathrm{mL})$ came from goats with healthy udders (not even affected by subclinical mastitis). Subclinical mastitis is rather hard to detect directly on a farm since it is not visually manifested by redness, swelling, fever, loss of appetite, or fatigue [31]. Twenty-three (out of the 34) milk samples were nearly mastitis-free (Table 2). These 23 samples were further subdivided into two groups with a lower (LZ) or higher (HZ) SCC than the particular SCC cut-off $\left(600,700,800\right.$, or $\left.1000.10^{3} / \mathrm{mL}\right)$; for instance, SCC $<600.10^{3} / \mathrm{mL}$ and SCC $>$ 
$600.10^{3} / \mathrm{mL}$. SCC cut-off 900 doesn't exist because no investigated milk sample contained SCC $900-999.10^{3} / \mathrm{mL}$. Each SCC cut-off group (low vs. high) was investigated for differences in the milk's chemical composition and technological parameters. Our results show that SCC influences milk yield, milk composition, and technological parameters (Table 4). The most striking differences were found for an SCC over $1000.10^{3} / \mathrm{mL}$ (6.32 LSCS), yet some differences appeared already in samples with an SCC over $600.10^{3} / \mathrm{mL}(5.58 \mathrm{LSCS}$, resp.) (milk yield, chlorides). From our results, any HZ group tended toward higher chloride content. Chloride ions (in the form of $\mathrm{NaCl}$ ) contribute to milk's osmotic pressure. Higher $\mathrm{NaCl}$ levels found in milk, however, negatively impact its technological parameters, such as rennetability (coagulation) and curd firmness [32].

With increasing SCC, the differences between $\mathrm{LZ}$ and HZ groups were more significant. In the HZ group of SCC $700.10^{3} / \mathrm{mL}$ (5.81 LSCS), we could observe increased protein and chloride contents, while lactose content decreased. A similar situation is seen in the group SCC $800.10^{3} / \mathrm{mL}$, where the heat stability starts to shorten. The most significant differences (between HZ and LZ groups) were found at SCC $1000.10^{3} / \mathrm{mL}$ (6.32 LSCS), at which the milk contained more non-fat dry matter (NFDM) caused by higher casein and protein contents. Moreover, the HZ group of samples (SCC $1000.10^{3} / \mathrm{mL}$ ) also had increased chloride levels. According to the literature, the relation between SCC and goat milk composition is still inconclusive [9,32], which might have been caused by insufficient correction for factors influencing milk composition. Leitner et al. [25], Bernacka [33], and Barrón-Bravo et al. [34] all found a positive correlation between SCC and protein content (caused by increased whey protein content). Our observations that SCC increases protein and casein contents are in line with data published by Stocco et al. [32].

Increased casein content in $\mathrm{HZ}$ (Staph. count $<100 \mathrm{CFU} / \mathrm{mL}$ and SCC $>1000.10^{3} / \mathrm{mL}$ ) could first appear as convenient, yet, in fact, result in inconvenient technological parameters such as heat stability and rennetability. This might have been caused by factors other than chlorides. It is important to underscore that somatic cells have their own enzymes which might influence the technological parameters of milk. Thus, increased milk SCC might lead to higher enzyme and enzyme activator/inhibitor content. In this respect Bagnicka et al. [5] as well as Alhussien et al. [3] found that PMN produce a variety of enzymes-cathepsin ( $\mathrm{B}$, C, D, L, G, S), elastase, lipoprotein lipase, and collagenase [6].

One of the most studied endogenous enzymes in milk is cathepsin D (a lysosomal aspartic endopeptidase), the activity of which is correlated with SCC [7,35]. $\alpha_{S 1^{-}}, \alpha_{S 2^{-}}, \beta-$ and $\mathrm{k}$-casein are all hydrolyzed by its active form [10]. Higher $\alpha_{\mathrm{S} 1}$ - and $\alpha_{\mathrm{S} 2}$-casein contents do increase coagulation time and curd firmness [36], whereas their (proteolytic) fragments might worsen the milk's technological parameters $[8,25]$. Our ongoing research aims to investigate how SCC influences casein content, casein fractions, and actual fragments being formed. From the information above, it is evident that the intricacies of endogenous enzymes (originating in somatic cells) are enormously complex. In 2013, Janjanam et al. [37] studied proteolytic fragments of epithelial cells in cow milk and identified 497 unique proteins ( 409 were found in the databases), and $18 \%$ were classified as enzymes. It is more than obvious that there is a need to not only investigate the relationship between SCC and goat milk quality, but also to pay closer attention to somatic cell differentiation and to the endogenous enzymes.

The preceding paragraphs (and Table 4) tried to explain the effects SCC had on milk quality in samples which were almost MCB-free (Staph. count $<100 \mathrm{CFU} / \mathrm{mL}$ ). We tried to describe those samples in great detail, since we feel that other studies devoted to SCC and goat milk quality do not sufficiently pay attention to somatic cells (from healthy udders) and bacteria (MCB). The results from these experiments do not sufficiently consider the possible colonization of the mammary gland by MCB. This is why we analyzed the SCC and milk quality in relation to MCB (Staphylococcus spp.), even though their contents were rather low (Table 5). In our evaluation, we divided the 34 milk samples into groups $Z$ (Staph. count $<100 / \mathrm{mL}$ ) and B (Staph. count $>100 / \mathrm{mL}$ ) and found no relationship to SCC (LSCS, resp.). Only lactose content was shown to differ significantly in these two groups. 


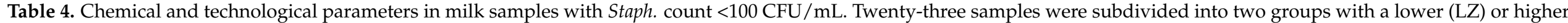
(HZ) SCC than the particular SCC cut-off $\left(600,700,800\right.$, or $\left.1000.10^{3} / \mathrm{mL}\right)$.

\begin{tabular}{|c|c|c|c|c|c|c|c|c|c|c|c|c|c|c|c|c|c|c|c|c|}
\hline Group & \multicolumn{2}{|c|}{ LZ } & \multicolumn{2}{|c|}{$\mathrm{HZ}$} & \multicolumn{3}{|c|}{$\mathbf{L Z}$} & \multicolumn{2}{|c|}{$\mathrm{HZ}$} & \multicolumn{3}{|c|}{ LZ } & \multicolumn{2}{|c|}{$\mathrm{HZ}$} & \multicolumn{3}{|c|}{ LZ } & \multicolumn{2}{|c|}{$\mathrm{HZ}$} & \multirow{4}{*}{$p$} \\
\hline $\begin{array}{c}\operatorname{SCC}\left(10^{3} / \mathrm{mL}\right)^{1} \\
\text { LSCS }^{2}\end{array}$ & & & & & \multirow[t]{3}{*}{$p$} & & & \multicolumn{2}{|c|}{$\begin{array}{l}>700 \\
>5.81\end{array}$} & $p$ & \multicolumn{2}{|c|}{$\begin{array}{l}<800^{*} \\
<6.00\end{array}$} & \multicolumn{2}{|c|}{$\begin{array}{l}>800^{*} \\
>6.00\end{array}$} & $p$ & \multicolumn{2}{|c|}{$\begin{array}{l}<1000 \\
<6.32\end{array}$} & \multicolumn{2}{|c|}{$\begin{array}{l}>1000 \\
>6.32\end{array}$} & \\
\hline \multirow{2}{*}{ Samples $(n)$} & \multicolumn{2}{|c|}{8} & \multicolumn{2}{|c|}{15} & & \multicolumn{2}{|c|}{9} & \multicolumn{2}{|c|}{14} & & \multicolumn{2}{|c|}{10} & \multicolumn{2}{|c|}{13} & & \multicolumn{2}{|c|}{12} & \multicolumn{2}{|c|}{11} & \\
\hline & Mean & SD & Mean & SD & & Mean & SD & Mean & SD & & Mean & SD & Mean & SD & & Mean & SD & Mean & SD & \\
\hline Milk yield (mL) & $669^{a}$ & 136 & $510^{\mathrm{b}}$ & 168 & 0.039 & 639 & 156 & 518 & 172 & 0.115 & 635 & 147 & 512 & 177 & 0.088 & 588 & 175 & 541 & 176 & 0.538 \\
\hline Rennetability (s) & 129 & 29.0 & 159 & 54.2 & 0.087 & 131 & 28.0 & 160 & 56.2 & 0.176 & 131 & 26.4 & 163 & 57.7 & 0.129 & 129 & 25.4 & 171 & 59.0 & 0.053 \\
\hline Heat stability (s) & 177 & 60.1 & 172 & 128 & 0.287 & 195 & 79.1 & 160 & 123 & 0.095 & $232^{a}$ & 137 & $129^{\mathrm{b}}$ & 45.9 & 0.020 & $217^{\text {a }}$ & 129 & $126^{\mathrm{b}}$ & 49.1 & 0.034 \\
\hline $\mathrm{pH}$ & 6.79 & 0.08 & 6.82 & 0.12 & 0.540 & 6.81 & 0.09 & 6.81 & 0.12 & 0.875 & 6.80 & 0.09 & 6.82 & 0.12 & 0.515 & 6.78 & 0.09 & 6.84 & 0.12 & 0.091 \\
\hline Fat $(\mathrm{g} / 100 \mathrm{~g})$ & 5.39 & 0.59 & 5.23 & 0.58 & 0.651 & 5.41 & 0.55 & 5.21 & 0.59 & 0.571 & 5.40 & 0.52 & 5.20 & 0.61 & 0.710 & 5.37 & 0.48 & 5.20 & 0.67 & 0.951 \\
\hline Protein $(\mathrm{g} / 100 \mathrm{~g})$ & 3.09 & 0.17 & 3.29 & 0.42 & 0.071 & $3.05^{\mathrm{b}}$ & 0.19 & $3.32^{\mathrm{a}}$ & 0.41 & 0.017 & $3.08^{\mathrm{b}}$ & 0.20 & $3.32^{\mathrm{a}}$ & 0.42 & 0.035 & $3.04^{\mathrm{b}}$ & 0.28 & $3.41^{\mathrm{a}}$ & 0.35 & 0.009 \\
\hline Lactose (g/100 g) & 4.68 & 0.18 & 4.56 & 0.13 & 0.093 & $4.69^{\mathrm{a}}$ & 0.17 & $4.55^{\mathrm{b}}$ & 0.13 & 0.038 & 4.67 & 0.17 & 4.55 & 0.13 & 0.094 & 4.64 & 0.17 & 4.56 & 0.14 & 0.325 \\
\hline Chlorides (mg/100 mL) & $145^{\mathrm{b}}$ & 13.9 & $160^{\mathrm{a}}$ & 12.2 & 0.024 & $146^{\mathrm{b}}$ & 13.4 & $161^{\mathrm{a}}$ & 12.5 & 0.027 & $146^{\mathrm{b}}$ & 12.7 & $162^{\mathrm{a}}$ & 12.4 & 0.013 & $147^{\mathrm{b}}$ & 11.6 & $164^{\mathrm{a}}$ & 12.3 & 0.004 \\
\hline $\mathrm{NFDM}^{3}(\mathrm{~g} / 100 \mathrm{~g})$ & 8.56 & 0.16 & 8.64 & 0.47 & 0.723 & 8.53 & 0.17 & 8.66 & 0.48 & 0.395 & 8.53 & 0.16 & 8.67 & 0.50 & 0.369 & $8.45^{\mathrm{b}}$ & 0.28 & $8.79^{\mathrm{a}}$ & 0.43 & 0.045 \\
\hline $\mathrm{TDM}^{4}(\mathrm{~g} / 100 \mathrm{~g})$ & 13.9 & 0.56 & 13.8 & 0.59 & 0.439 & 13.9 & 0.52 & 13.8 & 0.62 & 0.450 & 13.9 & 0.49 & 13.8 & 0.64 & 0.420 & 13.8 & 0.51 & 13.9 & 0.65 & 0.902 \\
\hline
\end{tabular}

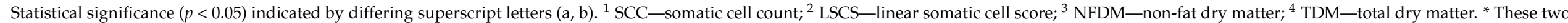
groups contain the same samples as they would for SCC $900.10^{3} / \mathrm{mL}$. 
Table 5. Chemical and technological parameters in milk samples according to MCB.

\begin{tabular}{|c|c|c|c|c|c|}
\hline \multirow[b]{2}{*}{ Group } & \multicolumn{2}{|c|}{$\mathbf{Z}$} & \multicolumn{2}{|c|}{ B } & \multirow{4}{*}{$p$} \\
\hline & $\begin{array}{r}S \\
<10\end{array}$ & & $\begin{array}{r}S \\
>10\end{array}$ & & \\
\hline \multirow{2}{*}{ Samples (n) } & \multicolumn{2}{|c|}{23} & \multicolumn{2}{|c|}{11} & \\
\hline & Mean & SD & Mean & SD & \\
\hline $\operatorname{SCC}\left(10^{3} / \mathrm{mL}\right)^{1}$ & 1.471 & 1.209 & 1.188 & 706 & 0.956 \\
\hline $\operatorname{LSCS}^{2}$ & 6.36 & 1.29 & 6.31 & 0.96 & 0.956 \\
\hline Milk yield (mL) & 565 & 173 & 614 & 142 & 0.397 \\
\hline Rennetability (s) & 149 & 48.6 & 149 & 34.9 & 0.659 \\
\hline Heat stability (s) & 174 & 107 & 147 & 92.2 & 0.397 \\
\hline $\mathrm{pH}$ & 6.81 & 0.11 & 6.84 & 0.07 & 0.418 \\
\hline Fat (g/100 g) & 5.29 & 0.57 & 5.80 & 1.85 & 0.672 \\
\hline Protein $(\mathrm{g} / 100 \mathrm{~g})$ & 3.22 & 0.36 & 3.22 & 0.37 & 0.868 \\
\hline Casein $(\mathrm{g} / 100 \mathrm{~g})$ & 2.61 & 0.34 & 2.56 & 0.38 & 0.825 \\
\hline Lactose $(\mathrm{g} / 100 \mathrm{~g})$ & $4.60^{\mathrm{a}}$ & 0.16 & $4.47^{b}$ & 0.16 & 0.022 \\
\hline Chlorides (mg/100 mL) & 155 & 14.6 & 157 & 6.92 & 0.619 \\
\hline $\operatorname{NFDM}(\mathrm{g} / 100 \mathrm{~g})^{3}$ & 8.61 & 0.39 & 8.48 & 0.33 & 0.294 \\
\hline TDM $(\mathrm{g} / 100 \mathrm{~g})^{4}$ & 13.8 & 0.57 & 14.2 & 1.90 & 0.727 \\
\hline
\end{tabular}

Lactose contributes the most to milk osmosis and it also belongs to the most unchanging (conserved) milk components. During mastitis, lactose production in damaged epithelial cells decreases, and it can be reabsorbed from milk into blood plasma [38]. Silanikove et al. [8] published results on how subclinical mastitis affects basic milk components and showed that only lactose decreased in milk with $\mathrm{MCB}$, which was confirmed by our results as well. Leitner et al. [25] mention decreasing lactose content in MCB infected milk and conclude that lactose can be perused as an indicator of mammary gland inflammation. Leitner et al. [25] also found changes in other milk components due to subclinical mastitis, which is true neither for Silanikove et al. [8] nor for our results. As we have already mentioned, the results in our experiment are substantially influenced by low counts of (mostly coagulase-negative) Staphylococcus bacteria. Our results show that even a low count of coagulase-negative Staphylococcus bacteria nevertheless impacts milk quality. Many studies have confirmed that subclinical mastitis changes milk composition, which negatively influences nutritional and technological properties [8,39].

Our results confirmed our initial theory that both SCC and low counts of MCB impact goat milk quality. This realization made us divide the 34 samples into two groups (Table 6): LZ (with SCC $<1000.10^{3} / \mathrm{mL}$ and Staph. count $<100 \mathrm{CFU} / \mathrm{mL}$ ) and all remaining samples (LBHZHB). The SCC value $\left(<1000.10^{3} / \mathrm{mL}\right)$ in the LZ group above was chosen since (i) this SCC cut-off had the highest impact on milk quality (Table 4), (ii) milk quality is significantly influenced by Staph. count $>100 \mathrm{CFU} / \mathrm{mL}$ MCB, and (iii) the distribution of Staph. spp. in groups $\mathrm{L}$ and $\mathrm{H}$ is even (Table 3 ).

The LBHZHB group had significantly higher protein, chloride, $\mathrm{pH}$, and decreased lactose levels (Table 6). This group also tended toward an increased casein content. Most important, however, are the changes in technological parameters such as the lengthening of coagulation time, or shortened thermal stability, which might be caused by increased chloride content (as mentioned above) and/or $\mathrm{pH}$ change. A high $\mathrm{pH}$ in goat milk leads to increased curdling time and lower curd firmness [9,32]. It can be argued whether protein fragments originating from the activity of endogenous or exogenous enzymes in milk do also contribute to these observations. Higher casein content in those milk samples might cause the lengthening of coagulation time. As seen above, the division of samples into LZ vs. LBHZHB groups allowed us to reach clear conclusions about the impact on milk quality and technological properties. Goat farms should therefore screen routinely for these parameters to standardize and increase milk quality. 
Table 6. Chemical and technological parameters in milk samples according to SCC and MCB.

\begin{tabular}{|c|c|c|c|c|c|}
\hline Group & \multicolumn{2}{|c|}{ LZ } & \multicolumn{2}{|c|}{ LBHZHB } & \multirow{6}{*}{$p$} \\
\hline $\operatorname{SCC}\left(10^{3} / \mathrm{mL}\right)^{1}$ & \multicolumn{2}{|c|}{$<1000$} & \multicolumn{2}{|c|}{$*$} & \\
\hline LSCS $^{2}$ & \multicolumn{2}{|c|}{$<6.32$} & \multicolumn{2}{|c|}{$*$} & \\
\hline Staph. Count (CFU/mL) & & & & & \\
\hline \multirow{2}{*}{ Samples $(n)$} & \multicolumn{2}{|c|}{12} & \multicolumn{2}{|c|}{22} & \\
\hline & Mean & SD & Mean & SD & \\
\hline Milk yield (mL) & 588 & 175 & 577 & 160 & 0.857 \\
\hline Rennetability (s) & $129^{b}$ & 25.4 & $160^{\mathrm{a}}$ & 48.6 & 0.047 \\
\hline Heat stability (s) & $217^{\mathrm{a}}$ & 129 & $137^{\mathrm{b}}$ & 72.9 & 0.031 \\
\hline $\mathrm{pH}$ & $6.78^{b}$ & 0.09 & $6.84^{\mathrm{a}}$ & 0.09 & 0.045 \\
\hline Fat $(\mathrm{g} / 100 \mathrm{~g})$ & 5.37 & 0.48 & 5.50 & 1.39 & 0.857 \\
\hline Protein $(\mathrm{g} / 100 \mathrm{~g})$ & $3.04^{\mathrm{b}}$ & 0.28 & $3.31^{\mathrm{a}}$ & 0.37 & 0.031 \\
\hline Casein $(\mathrm{g} / 100 \mathrm{~g})$ & 2.44 & 0.23 & 2.68 & 0.38 & 0.066 \\
\hline Lactose $(\mathrm{g} / 100 \mathrm{~g})$ & $4.64^{\mathrm{a}}$ & 0.17 & $4.52^{\mathrm{b}}$ & 0.15 & 0.050 \\
\hline Chlorides (mg/100 mL) & $147^{\mathrm{b}}$ & 11.6 & $160^{\mathrm{a}}$ & 10.4 & 0.002 \\
\hline $\operatorname{NFDM}(\mathrm{g} / 100 \mathrm{~g})^{3}$ & 8.45 & 0.28 & 8.63 & 0.40 & 0.296 \\
\hline $\mathrm{TDM}(\mathrm{g} / 100 \mathrm{~g})^{4}$ & 13.8 & 0.51 & 14.0 & 1.40 & 0.719 \\
\hline
\end{tabular}

Statistical significance $(p<0.05)$ indicated by differing superscript letters $(\mathrm{a}, \mathrm{b}) .{ }^{*}$ See Table $2 .{ }^{1}$ SCC-somatic cell count; ${ }^{2}$ LSCS-linear somatic cell score; ${ }^{3}$ NFDM-non-fat dry matter; ${ }^{4}$ TDM-total dry matter.

\section{Conclusions}

Somatic cell count (SCC) is still being neglected as a quality parameter in goat milk in the Czech Republic. In our study we were able to show the evidence for changes in milk quality with SCC $>600.10^{3} / \mathrm{mL}$ (5.58 LSCS) in a farm maintaining very high sanitation standards and without any significant presence of mastitis-causing bacteria (MCB) in the mammary gland. Generally speaking, an increasing SCC value in milk alters its technological properties. We argue that SCC is a neglected criterion that is able to impact dairy processing. Mastitis-causing bacteria in the mammary gland can alter milk quality, even when the microbial count is within the allowable limits for bulk milk mandated by the legislation. We hope that these results will lead to a better understanding of the problem and that they will increase both farmers' knowledge and overall goat milk quality.

Author Contributions: Conceptualization, K.P. and M.B.; Methodology, K.P. and M.B.; Data curation, K.P. and M.B.; Formal analysis, K.P.; Funding acquisition, K.P. and O.E.; Investigation, K.P., M.B., R.S., H.D., Martina Švejcarová (M.Š.), J.P.; Project administration, M.B. and K.P.; Resources O.E., K.P., H.D. and R.S.; Supervision, M.B. and O.E.; Validation, Martina Švejcarová (M.Š.); Writing—original draft, K.P. and M.B.; Writing—review and editing; Miloslav Šulc (M.Š.), M.B. and K.P. All authors have read and agreed to the published version of the manuscript.

Funding: This research was supported by the Ministry of Agriculture of the Czech Republic, institutional support MZE-RO1420, MZE-RO0318 and by Czech University of Life Science Prague, Faculty of Agrobiology, Food and Natural Resources (GA FAPPZ SV19-04-21120).

Institutional Review Board Statement: Ethical review and approval were waived for this study, due to the fact, that there was no experiment on animals according to Czech National Council Act No. 246/1992 Coll. "on the protection of animals against cruelty", as amended by later regulations in § 3 letter $\mathrm{j}$ since milk was obtained from the animals only by milking.

Informed Consent Statement: Not applicable.

Data Availability Statement: The data presented in this study are available on request from the corresponding author.

Conflicts of Interest: The authors declare no conflict of interest. 


\section{References}

1. Paape, M.J.; Capuco, A.V. Cellular defense mechanisms in the udder and lactation of goats. J. Anim. Sci. 1997, 75, 556-565. [CrossRef]

2. Jimenez-Granado, R.; Sanchez-Rodriguez, M.; Arce, C.; Rodriguez-Estevez, V. Factors affecting somatic cell count in dairy goats: A review. Span. J. Agric. Res. 2014, 12, 133-150. [CrossRef]

3. Alhussien, M.N.; Dang, A.K. Milk somatic cells, factors influencing their release, future prospects, and practical utility in dairy animals: An overview. Vet. World 2018, 11, 562-577. [CrossRef]

4. Paape, M.J.; Poutrel, B.; Contreras, A. Milk Somatic Cells and Lactation in Small Ruminants. J. Dairy Sci. 2001, 84, 237-244. [CrossRef]

5. $\quad$ Bagnicka, E.; Winnicka, A.; Jóźwik, A.; Rzewuska, M.; Strzałkowska, N.; Kósciuczuk, E.; Prusak, B.; Kaba, J.; Horbańczuk, J.; Krzyzewski, J. Relationship between somatic cell count and bacterial pathogens in goat milk. Small Rumin. Res. 2011, $100,72-77$. [CrossRef]

6. Moradi, M.; Omer, A.K.; Razavi, R.; Valipour, S.; Guimarães, J.T. The relationship between milk somatic cell count and cheese production, quality and safety: A review. Int. Dairy J. 2021, 113, 104884. [CrossRef]

7. Albenzio, M.; Santillo, A.; Kelly, A.L.; Caroprese, M.; Marino, R.; Sevi, A. Activities of indigenous proteolytic enzymes in caprine milk of different somatic cell counts. J. Dairy Sci. 2015, 98, 7587-7594. [CrossRef]

8. Silanikove, N.; Merin, U.; Shapiro, F.; Leitner, G. Subclinical mastitis in goats is associated with upregulation of nitric oxidederived oxidative stress that causes reduction of milk antioxidative properties and impairment of its quality. J. Dairy Sci. 2014, 97, 3449-3455. [CrossRef]

9. Raynal-Ljutovac, K.; Pirisi, A.; de Crémoux, R.; Gonzalo, C. Somatic cells of goat and sheep milk: Analytical, sanitary, productive and technological aspects. Small Rumin. Res. 2007, 68, 126-144. [CrossRef]

10. Li, N.; Richoux, R.; Boutinaud, M.; Martin, P.; Gagnaire, V. Role of somatic cells on dairy processes and products: A review. Dairy Sci. Technol. 2014, 94, 517-538. [CrossRef]

11. Bogdanovičová, K.; Vyletělová-Klimešová, M.; Babák, V.; Kalhotka, L.; Koláčková, I.; Karpíšková, R. Microbiological Quality of Raw Milk in the Czech Republic. Czech J. Food Sci. 2016, 3, 189-196. [CrossRef]

12. Novotná, K.; Svitáková, A.; Rychtářová, J.; Fantová, M.; Nohejlová, L. Methodology of udder description and the effect on somatic cell count in Czech White Shorthaired goat breed. Med. Weter. 2018, 74, 497-500. [CrossRef]

13. Wiggans, G.; Shook, G. A Lactation Measure of Somatic Cell Count. J. Dairy Sci. 1987, 70, 2666-2672. [CrossRef]

14. ČSN EN ISO 4833-1. Microbiology of the food chain-Horizontal method for the enumeration of microorganisms-Part 1: Colony count at 30 degrees $C$ by the pour plate technique. In Czech Technical Standards; Czech Office for Standards, Metrology and Testing: Prague, Czech Republic, 2014. Available online: https:/ / www.iso.org/standard/53728.html (accessed on 2 March 2021).

15. Desobry-Banon, S.; Richard, F.; Hardy, J. Study of Acid and Rennet Coagulation of High Pressurized Milk. J. Dairy Sci. 1994, 77, 3267-3274. [CrossRef]

16. Robitaille, G.; Ayers, C. Effects of K-casein glycosylation on heat stability of milk. Food Res. Int. 1995, 28, 17-21. [CrossRef]

17. ČSN EN ISO 1211. Milk-Determination of Fat Content-Gravimetric Method (Reference Method). In Czech Technical Standards; Czech Office for Standards, Metrology and Testing: Prague, Czech Republic, 2011. Available online: https://www.iso.org/ standard/51348.html (accessed on 10 April 2021).

18. ČSN EN ISO 8968-1. Milk and Milk Products—Determination of Nitrogen Content-Part 1: Kjeldahl Principle and Crude Protein Calculation. In Czech Technical Standards; Czech Office for Standards, Metrology and Testing: Prague, Czech Republic, 2014. Available online: https:/ /www.iso.org/standard/61020.html (accessed on 10 April 2021).

19. ČSN ISO 17997-1. Milk—Determination of Casein-Nitrogen Content_Part 1: Indirect Method (Reference Method). In Czech Technical Standards; Czech Office for Standards, Metrology and Testing: Prague, Czech Republic, 2006. Available online: https:// www.iso.org/standard/31670.html (accessed on 10 April 2021).

20. IDF 79-2. Dried Milk Ice-Mixes and Processed Cheese-Determination of Lactose Content, Part 2: Enzymatic Method Utilizing the Galactose Moiety of the Lactose. In International Standards; International Dairy Federation: Brussels, Belgium, 2002. Available online: https://www.sis.se/api/document/preview/902571/ (accessed on 10 April 2021).

21. ČSN ISO 6731. Milk, Cream and Evaporated Milk-Determination of Total Solids Content (Reference Method). In Czech Technical Standards; Czech Office for Standards, Metrology and Testing: Prague, Czech Republic, 2011. Available online: https:// www.iso.org/standard/56815.html (accessed on 10 April 2021).

22. ČSN 57 0530. Milk and Milk Product Testing Methods. In Czech Technical Standards; Czech Office for Standards, Metrology and Testing: Prague, Czech Republic, 1972.

23. Ceballos, L.S.; Morales, E.R.; de la Torre Adarve, G.; Castro, J.D.; Martínez, L.P.; Sampelayo, M.R.S. Composition of goat and cow milk produced under similar conditions and analyzed by identical methodology. J. Food Compos. Anal. 2009, 22, 322-329. [CrossRef]

24. Goetsch, A.L.; Zeng, S.S.; Gipson, T.A. Factors affecting goat milk production and quality. Small Rumin. Res. 2011, 101, 55-63. [CrossRef]

25. Leitner, G.; Merin, U.; Silanikove, N. Changes in Milk Composition as Affected by Subclinical Mastitis in Goats. J. Dairy Sci. 2004, 87, 1719-1726. [CrossRef] 
26. Vyhláška č. 445/2017 Sb., Kterou se Mění Vyhláška č. 128/2009 Sb., o Přizpůsobení Veterinárních a Hygienických Požadavků pro Některé Potravinářské Podniky, v Nichž se Zachází se Živočišnými Produkty, ve Znění Vyhlášky č. 191/2013 Sb. Available online: https: / / www.zakonyprolidi.cz/cs/2017-445 (accessed on 22 March 2021).

27. Zeng, S.S.; Escobar, E.N. Effect of breed and milking method on somatic cell count, standard plate count and composition of goat milk. Small Rumin. Res. 1996, 19, 169-175. [CrossRef]

28. Paape, M.J.; Wiggans, G.R.; Bannerman, D.D.; Thomas, D.L.; Sanders, A.H.; Contreras, A.; Moroni, P.; Miller, R.H. Monitoring goat and sheep milk somatic cell counts. Small Rumin. Res. 2007, 68, 114-125. [CrossRef]

29. Mehdid, A.; Martí-De Olives, A.M.; De Fernández, N.; Rodríguez, M.; Peris, C. Effect of stress on somatic cell count and milk yield and composition in goats. Res. Vet. Sci. 2019, 125, 61-70. [CrossRef]

30. Leitner, G.; Merin, U.; Lavi, Y.; Egber, A.; Silanikove, N. Aetiology of intramammary infection and its effect on milk composition in goat flocks. J. Dairy Res. 2007, 74, 186-193. [CrossRef]

31. Rupp, R.; Huau, C.; Caillat, H.; Fassier, T.; Bouvier, F.; Pampouille, E.; Clément, V.; Palhière, I.; Larroque, H.; Tosser-Klopp, G.; et al. Divergent selection on milk somatic cell count in goats improves udder health and milk quality with no effect on nematode resistance. J. Dairy Sci. 2019, 102, 5242-5253. [CrossRef] [PubMed]

32. Stocco, G.; Pazzola, M.; Dettori, M.L.; Cipolat-Gotet, C.; Summer, A.; Vacca, G.M. Variation in caprine milk composition and coagulation as affected by udder health indicators. Int. Dairy J. 2019, 98, 9-16. [CrossRef]

33. Bernacka, H. Cytological Quality of Goat Milk on the Basis of the Somatic Cell Count. Jakośc Cytol. Mleka Kóz Na Podstawie Zawartości Komórek 2007, 7, 773-778.

34. Barrón-Bravo, O.G.; Gutiérrez-Chávez, A.J.; Ángel-Sahagún, C.A.; Montaldo, H.H.; Shepard, L.; Valencia-Posadas, M. Losses in milk yield, fat and protein contents according to different levels of somatic cell count in dairy goats. Small Rumin. Res. 2013, 113, 421-431. [CrossRef]

35. Hurley, M.J.; Larsen, L.B.; Kelly, A.L.; McSweeney, P.L.H. The milk acid proteinase cathepsin D: A review. Int. Dairy J. 2000, 10, 673-681. [CrossRef]

36. Clark, S.; Sherbon, J.W. Alpha(s1)-casein, milk composition and coagulation properties of goat milk. Small Rumin. Res. 2000, 38, 123-134. [CrossRef]

37. Janjanam, J.; Jamwal, M.; Singh, S.; Kumar, S.; Panigrahi, A.K.; Hariprasad, G.; Jena, M.K.; Anand, V.; Kumar, S.; Kaushik, J.K.; et al. Proteome analysis of functionally differentiated bovine (Bos indicus) mammary epithelial cells isolated from milk. Proteomics 2013, 13, 3189-3204. [CrossRef]

38. Gonçalves, J.L.; Tomazi, T.; Barreiro, J.R.; Beuron, D.C.; Arcari, M.A.; Lee, S.H.I.; Marlon de Magalhães Rodrigues Martins, C.; Araújo Junior, J.P.; Veiga dos Santos, M. Effects of bovine subclinical mastitis caused by Corynebacterium spp. on somatic cell count, milk yield and composition by comparing contralateral quarters. Vet. J. 2016, 209, 87-92. [CrossRef]

39. Merin, U.; Fleminger, G.; Komanovsky, J.; Silanikove, N.; Bernstein, S.; Leitner, G. Subclinical udder infection with Streptococcus dysgalactiae impairs milk coagulation properties: The emerging role of proteose peptones. Dairy Sci. Technol. 2008, 88, 407-419. [CrossRef] 